\title{
Pengaruh Motivasi terhadap Semangat Kerja Pegawai pada Kantor Balai Diklat Keuangan Palembang
}

\author{
Yetty Komala Sari ${ }^{1)}$ \\ 1) Balai Diklat Keuangan Palembang \\ Email: yettyharsyah@gmail.com ${ }^{1}$
}

\begin{abstract}
Abstrak
Penelitian ini bertujuan untuk mengetahui besarnya pengaruh motivasi terhadap semangat kerja pegawai pada kantor Balai Diklat Keuangan Palembang. Penelitian ini merupakan penelitian deskriptif kualitatif dengan jumlah sampel sebanyak 52 orang responden, sedangkan teknik pengambilan sampel yang digunakan dalam penelitian ini adalah sampel jenuh. Pada penelitian ini variabel bebasnya yaitu motivasi dan variabel terikatnya semangat kerja. Hasil penelitian ini diketahui dari hasil uji koefisien korelasi di peroleh nilai sebesar 0,736 atau 73,6\% yang berarti hubungan motivasi dengan semangat kerja yaitu kuat, selanjutnya dilakukan uji koefisien determinasi diketahui bahwa motivasi berpengaruh terhadap semangat kerja pegawai pada kantor Balai Diklat Keuangan Palembang sebesar 54,2\% dan sisanya di pengaruhi oleh variabel lain.
\end{abstract}

Kata Kunci: motivasi, semangat kerja, manajemen SDM, Indonesia

\section{Pendahuluan}

Penyelenggaraan pelayanan publik baik swasta maupun pemerintahan yang baik dapat dilihat melalui kualitas pelayanannya. Pelayanan prima merupakan kualitas pelayanan yang diidamidamkan oleh semua pihak. Untuk memberikan pelayanan prima, maka semangat kerja pegawai harus ditingkatkan. Dalam upaya meningkatkan pelayanan publik tersebut diperlukan adanya semangat dalam bekerja. Untuk itu perlu adanya upaya untuk meningkatkan semangat kerja seseorang atau sekelompok orang melalui pemberian motivasi.

Dengan adanya pemberian motivasi, maka seseorang (pegawai/karyawan) dapat menimbulkan dorongan atau keadaan. Jadi dapat pula dikatakan bahwa motivasi adalah faktor yang mendorong orang untuk bertindak secara sederhana untuk mencapai tujuan organisasi atau perusahaan.

Seperti diketahui, Balai Diklat Keuangan Palembang merupakan instansi pemerintah pusat yang mengemban dan mempunyai tugas khusus secara teknis memberikan pelayanan pendidikan dan pelatihan bagi peserta diklat dan mendukung program-program lainnya di kementerian keuangan.

Dalam hal ini, Balai Diklat Keuangan Palembang dituntut untuk bisa meningkatkan kualitas organisasi, misalnya dari segi internal organisasi itu sendiri antara lain peningkatan kualitas pegawai. Kualitas pegawai dapat dilihat dari semangat dan disiplin kerja yang dilakukan seharihari. Dengan adanya semangat dan disiplin kerja yang tinggi diharapkan dapat meningkatkan kinerja organisasi.

Dari hasil pemantauan selama bekerja, kondisi semangat dan disiplin kerja dilingkungan kantor Balai Diklat Keuangan Palembang menunjukkan masih belum optimal. Hal ini tercermin dari masih ada pegawai yang belum menaati peraturan yang berlaku, misalnya datang kekantor lebih lambat atau pulang lebih cepat dari waktu bekerja yang ditentukan. Penegakan aturan dan 
pemberian sanksi juga masih belum optimal, hal ini terlihat dari tidak jelas dan tidak konsistennya pemberian sanksi tersebut diberlakukan.

Selain itu, berdasarkan hasil pengamatan, masih ditemukannya beberapa pegawai yang sulit terpusat pada pekerjaannya dan sikap yang kurang semangat dan tidak disiplin dilihat dari masih adanya beberapa pegawai yang saat pada jam kerja tetapi mereka tidak bekerja, hal ini cukup menggangu aktivitas kegiatan kerja, sehingga dalam menyelesaikan tugas pun tidak sesuai dengan jumlah dan waktu yang telah ditentukan dan berdampak pada visi dan misi instansi pun akan tercapai lebih lama dari yang diinginkan.

Dari latar belakang masalah sebagaimana diuraikan di atas dapat dikatakan bahwa untuk mencapai semangat kerja yang tinggi maka diperlukan motivasi dalam bekerja. Berdasarkan identifikasi masalah di atas, maka permasalahan yang diajukan adalah:

1. Bagaimana motivasi pegawai di kantor Balai Diklat Keuangan Palembang?

2. Bagaimana semangat kerja pegawai di kantor Balai Diklat Keungan Palembang?

3. Bagaimana pengaruh motivasi terhadap semangat kerja pegawai di Kantor Balai Diklat Keuangan Palembang

\section{Tinjauan Pustaka}

\subsection{Motivasi}

Abraham Maslow $(1943 ; 1970)$ mengemukakan bahwa pada dasarnya semua manusia memiliki kebutuhan pokok. Ia menunjukkannya dalam 5 tingkatan yang berbentuk piramid, orang memulai dorongan dari tingkatan terbawah. Lima tingkat kebutuhan itu dikenal dengan sebutan Hirarki Kebutuhan Maslow, dimulai dari kebutuhan biologis dasar sampai motif psikologis yang lebih kompleks; yang hanya akan penting setelah kebutuhan dasar terpenuhi. Kebutuhan pada suatu peringkat paling tidak harus terpenuhi sebagian sebelum kebutuhan pada peringkat berikutnya menjadi penentu tindakan yang penting.

Motivasi merupakan istilah yang awalnya berasal dari bahasa Latin, Movere, yang berarti "bergerak". Sedangkan sejumlah definisi itu dapat ditemukan dalam literatur saat ini, tapi tidak ada definisi yang menggambarkan motivasi memadai. Sebuah analisis dari definisi utama menunjukkan motivasi terutama berkaitan dengan tiga faktor:apa yang memberikan energi perilaku, apa yang mengarahkan atau saluran perilaku seperti itu, dan bagaimana perilaku ini dipertahankan atau berkelanjutan, (Edison et al, 2018:172) dikutif dari (Sherman, et al., 199, hal.290).

\subsection{Semangat Kerja}

Menurut Hasanah (2016) mengatakan bahwa semangat kerja adalah kemampuan sekelompok orang untuk bekerjasama dengan giat dan konsekuen dalam mencapai tujuan bersama. Semangat kerja adalah keadaan psikologi seseorang berupa kesungguhan dan keinginan yang kuat untuk bekerja lebih giat agar tujuan yang diinginkan dapat tercapai. Indikator yang digunakan dalam kuesioner meliputi kegairahan atau antusiasme, kekuatan untuk melawan frustasi, kualitas untuk bertahan, dan semangat untuk berkelompok (Wardani et al, 2017) dikutip dari (Maier dalam Tenggara, 2012) dengan jurnal berjudul Pengaruh Kemampuan kerja dan semangat kerja terhadap kinerja Karyawan melalui kepuasan kerja (Studi Kasus Bank Syariah Mandiri Kantor Cabang Kendal). 


\subsection{Hubungan antara Motivasi dan Semangat Kerja}

Motivasi kerja juga berhubungan erat dengan semangat kerja, karna motivasi adalah penggerak daripada individu untuk melakukan aktivitas tertentu dalam mencapai tujuan. Dengan memberikan motivasi yang tepat, karyawan akan terdorong untuk berbuat semaksimal mungkin dalam melaksanakan tugasnya, dan mereka meyakini bahwa dengan keberhasilan organisasi mencapai tujuan dan berbagai sasarannya, maka kepentingan-kepentingan pribadinya akan terpelihara pula (Busro, $2018: 51$ ).

\section{Metodologi}

\subsection{Ruang Lingkup dan Objek Penelitian}

Penelitian ini akan membahas masalah yang berkaitan dengan pengaruh motivasi terhadap semangat kerja pegawai pada Kantor Balai Diklat Keuangan Palembang. Adapun objek penelitian ini yaitu : motivasi terhadap semangat kerja pegawai kantor Balai Diklat Keuangan Palembang.

\subsection{Waktu dan Batasan Penelitian}

Penelitian ini akan dilaksanakan pada Kantor Balai Diklat Keuangan Palembang bertempat di Jalan Sukabangun II, Sukarami, Palembang, Sumatera Selatan - 30151. Waktu penelitian ini di rencanakan akan dilakukan pada bulan September 2019 sampai Desember 2019. Berdasarkan identifikasi masalah yang dipaparkan sebelumnya, supaya penelitian ini lebih fokus tidak meluas dari pembahasan yang dimaksud maka dalam penelitian ini, penulis membatasi permasalahan yang dikaji pada ruang lingkup Pengaruh Motivasi Kerja Terhadap Semangat Kerja Pegawai kantor Balai Diklat Keuangan Palembang.

\subsection{Jenis dan Sumber Data}

a. Jenis Data

Data kualitatif merupakan data yang diperoleh dalam bentuk kata-kata, kalimat, dan gambar, data kualitatif dapat diperoleh dari hasil wawancara dengan pimpinan dan pegawai/karyawan di Kantor Balai Diklat Keuangan Palembang, serta informasi dari sumber lain yang berkaitan dengan masalah yang diteliti.

b. Sumber Data

1. Data primer yang merupakan data yang diperoleh dari sumbernya langsung, dengan melalui kuesioner, observasi, dan wawancara secara langsung dengan pegawai di Kantor Balai Diklat Keuangan Palembang sesuai dengan kebutuhan penelitian ini.

2. Data Sekunder yaitu data yang sudah tersedia yang diperoleh berdasarkan buku-buku penuntun yang ada di perpustakaan ataupun di internet jurnal yang merupakan referensi bagi penulis dalam menyusun skripsi nantinya.

\subsection{Teknik Pengumpulan Data}

Kuisioner adalah sejumlah pertanyaan tertulis yang digunakan untuk memperoleh informasi dan responden dalam arti laporan tentang metode kuisioner yang dipakai dalam penelitian ini adalah jenis kuisioner terbuka. Populasi adalah keseluruhan subjek penelitian (Suharsimi Arikunto, 1998 ), sedangkan pendapat lain, mengatakan bahwa populasi adalah seluruh penduduk / individu yang dimaksud untuk diselidiki (Sutrisno Hadi, 1994). Populasi dalam penelitian ini adalah seluruh pegawai kantor pada Balai Diklat Keuangan Palembang. Sampel 
adalah sebagian /wakil populasi yang diteliti apabila subjeknya kurang dari 100 lebih baik diambil semua sehingga penelitian merupakan penelitian populasi (Sukarsimi Arikunto, 1998). Mengingat jumlah karyawan dilingkungan kantor Pada Balai Pendidikan dan Pelatihan Keuangan Palembang kurang dari 100, yaitu 52 orang berdasarkan ketentuan tersebut di atas peneliti mengadakan penelitian pada seluruh populasi, dengan demikian peneliti ini tidak memakai sampel penelitian.

\section{Hasil dan Pembahasan}

\subsection{Uji Validitas}

Digunakan untuk mengukur sah (valid) atau tidaknya suatu kuesioner. Suatu kuesioner dikatakan valid jika pertanyaan pada kuesioner mampu untuk mengungkap suatu yang akan diukur oleh kuesioner tersebut. Uji validitas dihitung dengan membandingkan nilai $r$ hitung (correlated item-total correlation) dengan nilai $r$ tabel. jika $r$ hitung $>r$ tabel dan nilai positif maka butir atau pertanyaan tersebut dinyatakan valid (Ghozali, 2013).

Tabel 1. Hasil uji validititas variabel motivasi (X)

\begin{tabular}{|c|c|c|c|}
\hline ITEM & $\mathrm{R}_{\text {Hitung }}$ & $\mathrm{R}_{\text {Tabel }}$ & KETERANGAN \\
\hline Motivasi 1 & 0.761 & 0.273 & Valid \\
\hline Motivasi 2 & 0.778 & 0.273 & Valid \\
\hline Motivasi 3 & 0.761 & 0.273 & Valid \\
\hline Motivasi 4 & 0.778 & 0.273 & Valid \\
\hline Motivasi 5 & 0.576 & 0.273 & Valid \\
\hline Motivasi 6 & 0.795 & 0.273 & Valid \\
\hline Motivasi 7 & 0.425 & 0.273 & Valid \\
\hline Motivasi 8 & 0.390 & 0.273 & Valid \\
\hline Motivasi 9 & 0.795 & 0.273 & Valid \\
\hline Motivasi 10 & 0.448 & 0.273 & Valid \\
\hline
\end{tabular}

Berdasarkan tabel 1 di atas nilai $\mathrm{R}_{\text {Hitung }}$ untuk masing-masing pertanyaan bernilai antara 0,390 sampai 0,795 sedangkan $\mathrm{R}_{\text {Tabel }}$ bernilai 0,273 , sehingga semua nilai dalam pertanyaan di $\mathrm{R}_{H i t u n g}$ pada variabel $\mathrm{X}$ lebih besar dari $\mathrm{R}_{\text {Tabel }}$ dan seluruh pertanyaan dinyatakan valid.

Berdasarkan table 2 di atas nilai $\mathrm{R}_{\text {Hitung }}$ untuk masing-masing pertanyaan bernilai antara 0,415 sampai 0,762 sedangkan $\mathrm{R}_{\text {Tabel }}$ bernilai 0,273 , sehingga semua nilai dalam pertanyaan di $\mathrm{R}_{\text {Hitung }}$ pada variabel $\mathrm{Y}$ lebih besar dari $\mathrm{R}_{\text {Tabel }}$ dan seluruh pertanyaan dinyatakan valid. 
Tabel 2. Hasil uji validititas variabel motivasi (X)

\begin{tabular}{|l|c|c|c|}
\hline \multicolumn{1}{|c|}{ ITEM } & $\mathrm{R}_{\text {Hitung }}$ & $\mathrm{R}_{\text {Tabel }}$ & KETERANGAN \\
\hline Semangat Kerja 1 & 0.479 & 0.273 & Valid \\
\hline Semangat Kerja 2 & 0.415 & 0.273 & Valid \\
\hline Semangat Kerja 3 & 0.757 & 0.273 & Valid \\
\hline Semangat Kerja 4 & 0.762 & 0.273 & Valid \\
\hline Semangat Kerja 5 & 0.478 & 0.273 & Valid \\
\hline Semangat Kerja 6 & 0.557 & 0.273 & Valid \\
\hline Semangat Kerja 7 & 0.507 & 0.273 & Valid \\
\hline Semangat Kerja 8 & 0.557 & 0.273 & Valid \\
\hline Semangat Kerja 9 & 0.507 & 0.273 & 0.273 \\
\hline Semangat Kerja 10 & 0.557 & & \\
\hline
\end{tabular}

\subsection{Uji Reliabilitas}

Data untuk mengukur suatu kuesioner yang merupakan indikator dari variabel atau konstruk. Suatu kuesioner dikatakan reliable atau handal jika jawaban seseorang terhadap pertanyaan adalah konsisten atau stabil dari waktu ke waktu. Kehandalan yang menyangkut kekonsistenan jawaban jika diujikan berulang pada sampel yang berbeda. SPSS memberikan fasilitas untuk mengukur realibilitas dengan uji statistik Cronbach Alpha $(\alpha)$ suatu konstruk atau variabel dikatakan reliable jika memberikan nilai Cronbach Alpha >0,60 (Ghozali, 2013).

Tabel 3. Hasil uji reliabilitas

\begin{tabular}{|l|c|c|c|}
\hline \multicolumn{1}{|c|}{ Variabel } & Cronchbach's Alpha & Ketentuan R tabel & Hasil \\
\hline Motivasi & 0.846 & 0.6 & Reliabel \\
\hline Semangat Kerja & 0.751 & 0.6 & Reliabel \\
\hline
\end{tabular}

\subsection{Koefisien Korelasi $(R)$}

Koefisien korelasi adalah nilai yang menunjukan kuat atau tidaknya hubungan linier antara dua variabel. Koefisien korelasi biasa dilambangkan dengan huruf $r$ dimana nilai $r$ dapat bervariasi dari -1 sampai +1 . Nilai $r$ yang mendekati -1 atau +1 menunjukan hubungan yang kuat antara dua variabel nilai $r$ yang mendekati 0 mengidikasikan lemahnya hubungan antara dua variabel tersebut. 
Tabel 4. Hasil koefisien korelasi

\begin{tabular}{|l|r|r|r|r|}
\hline Model & R & R Square & \multicolumn{1}{|c|}{$\begin{array}{c}\text { Adjusted R } \\
\text { Square }\end{array}$} & Std. Error of the Estimate \\
\hline 1 &, $736^{\mathrm{a}}$ &, 542 &, 533 & 1,749 \\
\hline
\end{tabular}

a. Predictors: (Constant), TOTALX

b. Dependent Variable: TOTALLY

\subsection{Uji t (Statistik)}

Uji statistik $\mathrm{t}$ dimana untuk mengetahui apakah variabel bebas berpengaruh secara singnifikan terhadap variabel terkait. Serta untuk menguji pengaruh masing-masing variabel bebas yang digunakan dalam penelitian ini secara parsial digunakan uji t . Uji t dikenal uji parsial, yaitu untuk menguji bagaimana pengaruh masing-masing variabel bebas secara sendiri-sendiri terhadap variabel terikatnya.

Tabel 5. Menguji signifikan variabel Motivasi (X)

\begin{tabular}{|c|c|c|c|c|c|c|}
\hline \multirow{2}{*}{\multicolumn{2}{|c|}{ Model }} & \multicolumn{2}{|c|}{ Unstandardized Coefficients } & \multirow{2}{*}{$\begin{array}{c}\begin{array}{c}\text { Standardized } \\
\text { Coefficients }\end{array} \\
\text { Beta }\end{array}$} & \multirow[b]{2}{*}{$\mathrm{T}$} & \multirow[b]{2}{*}{ Sig. } \\
\hline & & B & Std. Error & & & \\
\hline \multirow[t]{2}{*}{1} & (Constant) & 19,113 & 3,484 & & 5,486 &, 000 \\
\hline & TOTALX & 609 &, 079 &, 736 & 7,698 &, 000 \\
\hline
\end{tabular}

a. Dependent Variable: TOTALLY

Bedasarkan data tabel 4.10 diperoleh $t_{\text {hitung }}$ sebesar 7,698 pada t-tabel lebih besar dari 0,05. Kriteria diterimanya hipotesis:

- Jika t-hitung $>$ t-tabel $<0,05$ maka $\mathrm{H}_{\mathrm{o}}$ ditolak dan $\mathrm{H}_{1}$ diterima.

- Jika t-hitung $<$ t-tabel $>0,05$ maka $\mathrm{H}_{\mathrm{o}}$ diterima dan $\mathrm{H}_{1}$ ditolak.

- Taraf nyata $=5 \%$ drajat kebebasan $(\mathrm{df})=\mathrm{n}-2=52-2=50$

Dari hasil perhitungan diatas diketahui bahwa nilai t-hitung $>$ t-tabel $<0,05$, yaitu 7,698 $>1,675$, hal ini berarti $\mathrm{H}_{\mathrm{o}}$ di tolak dan $\mathrm{H}_{1}$ diterima, sehingga dapat disimpulkan bahwa motivasi berpengaruh positif terhadap semangat kerja pegawai.

\subsection{Analisis Regresi Sederhana}

Tujuan dari teknik analisis regresi adalah untuk memprediksi bagaimana perubahan nilai yang terjadi pada variabel $\mathrm{X}$ dan variabel $\mathrm{Y}$ yang dimanipulasi (dinaikkan atau diturunkan nilainnya). Penelitian ini menggunakan analisis regresi linier sederhana. Menurut (Sujarweni, 2014) menjelaskan bahwa regresi liner sederhana merupakan regresi yang memiliki satu variabel dependen dan satu variabel independen. Model persamaan regresi linier sederhana dengan 
menggunakan rumus sebagai berikut: $Y=a+b X$

Keterangan:

$\mathrm{Y}=$ Variabel dependen, yaitu semangat kerja pegawai

$\mathrm{a}=$ Konstanta, yaitu titik potong kurva tehadap sumbu $\mathrm{Y}$

$\mathrm{b}=$ Koefisien regresi, yaitu kemiringan kurva linear

$\mathrm{X}=$ Variabel independen, yaitu motivasi

Tabel 6. Hasil uji linier sederhana

\section{Coefficients $^{\mathrm{a}}$}

\begin{tabular}{|c|c|c|c|c|c|c|}
\hline \multirow{2}{*}{\multicolumn{2}{|c|}{ Model }} & \multicolumn{2}{|c|}{ Unstandardized Coefficients } & \multirow{2}{*}{$\begin{array}{c}\begin{array}{c}\text { Standardized } \\
\text { Coefficients }\end{array} \\
\text { Beta }\end{array}$} & \multirow[b]{2}{*}{$\mathrm{t}$} & \multirow[b]{2}{*}{ Sig. } \\
\hline & & B & Std. Error & & & \\
\hline 1 & (Constant) & 19,113 & 3,484 & & 5,486 &, 000 \\
\hline & TOTALX & 609 & 079 & ,736 & 7,698 & 000 \\
\hline
\end{tabular}

a. Dependent Variable: TOTALLY

Persamaan regresi tersebut jika dimasukan ke dalam persamaan regresi $\mathrm{Y}=\mathrm{a}+\mathrm{bX}$ dapat dijelaskan sebagai berikut:

Hasil uji regresi sederhana menunjukan konstanta $a=19,113$ dan koefisien $b=0,609$. Sehingga persamaan regresi linier sederhana menjadi $Y=19,113+0,609 X$. Konstanta (a) sebesar 19,113 menyatakan bahwa jika tidak ada skor variabel motivasi $(X=0)$, maka skor variabel semangat kerja sebesar 19,113 dan Koefisien regresi variabel motivasi (X) mempunyai arah koefisien regresi positif dengan variabel semangat kerja pegawai yaitu $b=0,609$ artinya: Jika variabel motivasi mengalami peningkatan sebesar 1 maka variabel semangat kerja akan mengalami peningkatan pula sebesar $(0,609)$.

\subsection{Koefisien Determinasi $\left(R^{2}\right)$}

Tabel 7. Koefisien determinasi $\left(\mathrm{R}^{2}\right)$

Model Summary ${ }^{\mathrm{b}}$

\begin{tabular}{|l|r|r|r|r|}
\hline Model & $\mathrm{R}$ & \multicolumn{1}{|c|}{ R Square } & Adjusted R Square & \multicolumn{2}{c|}{$\begin{array}{c}\text { Std. Error of the } \\
\text { Estimate }\end{array}$} \\
\hline 1 &, $736^{\mathrm{a}}$ &, 542 &, 533 & 1,749 \\
\hline
\end{tabular}

a. Predictors: (Constant), TOTALX

b. Dependent Variable: TOTALY 
Dimana model linier sederhana ini, akan dilihat besarnya kontribusi untuk variabel bebas secara bersama-sama terhadap variabel terkait dengan melihat besarnya koefisien determinasi totalnya $\left(\mathrm{R}^{2}\right)$. Jika $\left(\mathrm{R}^{2}\right)$ yang diperoleh mendekati 1 (satu) maka dapat dikatakan semangkin kuat model tersebut menerangkan hubungan variabel bebas terhadap variabel terkait.

Untuk mengetahui seberapa besar pengaruh $\mathrm{X}$ terhadap variabel $\mathrm{Y}$ dengan menggunakan koefisien determinasi $\left(\mathrm{R}^{2}\right)$ yang dinyatakan dalam persentase:

- Hasilnya sebagai berikut :

- $\mathrm{R}^{2}=0,542 \times 100 \%$

$$
=54,2 \%
$$

Dari hasil perhitungan tersebut maka dapat disimpulkan bahwa ada pengaruh variabel motivasi terhadap semangat kerja sebesar 54,2\%, selebihnya 45,8 \% dipengaruhi oleh variabel independent lainnya.

\section{Kesimpulan}

Berdasarkan hasil penelitian dan pembahasan yang telah dilakukan dalam penelitian pada babbab sebelumnya, maka dapat dibuat kesimpulan sebagai berikut:

1. Dari hasil penelitian melalui uji validitas menunjukkan bahwa motivasi kerja pada kantor balai diklat keuangan palembang cukup tinggi, hal ini dapat kita lihat pada kuesioner/pertanyaan nomor 6 dan 9 pada variabel motivasi mempunyai nilai paling besar diantara pertanyaan yang lain yaitu sebesar 0,795 dimana pertanyaan nomor 6 adalah mengenai tanggungjawab apabila diberi tambahan pekerjaan dan pertanyaan nomor 9 mengenai inisiatif dan kreatif dalam melaksanakan pekerjaan agar lebih mudah. Akan tetapi kuesioner tentang motivasi pada pertanyaan nomor 8 dan 10 pada variabel motivasi mempunyai nilai paling rendah diantara pertanyaan yang lain yaitu sebesar 0,390 dan 0,448 dimana pertanyaan nomor 8 adalah mengenai tingkat kepuasan dalam melakukan pekerjaan dan pertanyaan nomor 10 mengenai dorongan untuk mencapai tujuan dalam pekerjaan.

2. Semangat kerja pada kantor Balai Diklat Keuangan Palembang cukup tinggi, hal ini dapat kita lihat pada pertanyaan nomor 3 dan 4 pada variabel semangat kerja mempunyai nilai paling besar diantara pertanyaan yang lain yaitu sebesar 0,757 dan 0,762 dimana pertanyaan nomor 3 adalah mengenai kerjasama untuk saling membantu jika ada kesulitaan dalam hal pekerjaan dan pertanyaan nomor 4 mengenai lingkungan yang sehat untuk meningkatkan semangat kerja pegawai. Akan tetapi semangat kerja juga terdapat nilai rendah dapat kita lihat pada uji validitas kuesioner atau Pertanyaan nomor 2 dan 5 pada variabel semangat kerja mempunyai nilai paling rendah diantara pertanyaan yang lain yaitu sebesar 0,415 dan 0,478 dimana pertanyaan nomor 2 adalah suasana kantor yang mendukung tercapainya hasil kerja yang baik dan pertanyaan nomor 5 mengenai hubungan yang baik sesama rekan kerja didalam kantor dan di luar kantor.

3. Berdasarkan penjelasan tersebut menunjukkan bahwa variabel independen (Motivasi) berpengaruh secara positif terhadap variabel dependen (Semangat Kerja). Dapat kita lihat pada uji t melalui nilai hasil output spsss bahwa motivasi berpengaruh secara positif terhadap semangat kerja pegawai pada kantor Balai Diklat Keuangan Palembang karena $t_{\text {hitung }}$ sebesar 7,698 pada t-tabel lebih besar dari 0,05 yaitu 7,698>1,675, hal ini berarti $\mathrm{H}_{\mathrm{o}}$ 
di tolak dan $\mathrm{H}_{1}$ diterima, sehingga dapat disimpulkan bahwa motivasi berpengaruh positif terhadap semangat kerja pegawai.

Berdasarkan kesimpulan di atas, dapat dikemukakan beberapa saran sebagai berikut:

1. Kantor Balai Diklat Keuangan Palembang hendaknya perlu meningkatkan motivasi dalam hal kepuasan kerja para pegawai dalam pekerjaannya dan dorongan untuk mencapai tujuan perusahaan karna tergolong masih rendah yaitu senilai 0,390 dan 0,448 dengan menggunakan uji validitas pada lembar kuesioner/pertanyaan yang peneliti ajukan.

2. Kantor Balai Diklat Keuangan Palembang diharapkan seuntuk menjaga suasana kantor dengan baik dan berhubungan baik dengan sesama rekan kerja baik di luar kantor atau di dalam kantor agar semangat dalam bekerja. Semangat kerja pada kantor Balai Diklat Keuangan Palembang masih cukup rendah dalam hal suasana kantor yang kurang mendukung tercapainya hasil kerja yang baik dan hubungan dengan sesama rekan kerja dalam pekerjaan baik dikantor maupun diluar masih dikategorikan kurang baik dilihat dari nilai kuesioner/pertanyaan yang diajukan oleh peniliti yaitu senilai 0,415 dan 0,478 menggunakan uji validitas.

3. Kantor Balai Diklat Keuangan Palembang dapat memberikan pujian, penghargaan, tidak selalu berupa promosi jabatan, bonus,insentif, hadiah dan sebagainya tetapi membuat pegawai merasa dihargai di dalam perusahaan juga dapat membuat pegawai termotivasi dalam bekerja, karena apa yang telah dilakukan pegawai dihargai oleh perusahaan/kantor, sehingga perusahaan/kantor dapat menghasilkan semangat dalam bekerja para pegawai.

4. Pada faktor motivasi masih diperlukan adanya peningkatan hubungan yang baik antara pimpinan dan karyawan/pegawai, serta pimpinan perlu mendorong semangat kerja pegawai dalam bekerja. Para pimpinan perlu sering turun ke bawah menjalin komunikasi dengan para bawahan serta membimbing para pegawai agar bekerja secara baik, sehingga hal ini akan membuat para pegawai lebih termotivasi untuk bekerja lebih baik karena merasa mendapat dukungan dari pimpinan dalam menjalankan tugasnya.

\section{Referensi}

Andry Charistio. (2016).Pengaruh Motivasi terhdap Semangat Kerja Karyawan pada PD Mitra Anda di Pontianak. Bisma vo.1, No.3, Juli 2016 di https://journal.widyadharma.ac.id/index.php/bisma/article/view/192

Agusti, M.J., Johar, Dahnil, Kamener,Dahliana.,(2016). Pengaruh Motivasi, kompensasi dan Lingkungan kerja terhadap semangat kerja karyawan bagian pemasaran PT. Indosat Cabang Padang. Mahasiswa Jurusan Manajemen, Fakultas Ekonomi, Universitas Bung Hatta. Di : ejurnal.bunghatta.ac.id

Ayuningtyas, Arindha. (2014). Faktor-Faktor Yang Mempengaruhi Motivasi Karyawan Dalam Promosi Jabatan di PT. Harapan Jaya Globalindo. Universitas Negeri Yogyakarta di: https://eprints.uny.ac.id/15587/

Arikunto, Suharsimi. (2010). Prosedur Penelitian Suatu Pendekatan Praktik Edisi Revisi. Jakarta: Rineka Cipta.

Busro, Muhammad. (2018). Teori-Teori Manajemen Sumber Daya Manusia.Kencana: Jakarta.

Fitriani,Dewi. Dan Widianti,Wiwik.(2017).Motivasi Kerja Terhadap Kinerja Pegawai pada Dinas Kependudukan dan Pencatatan Sipil Kota Depok. Cakrawala, Vol. XVII, No. 2, 
September 2017. di : ejournal.bsi.ac.id

Ghozali, I. (2013). Metode Penelitian. Bandung: Pustaka Setia.

Hadi, Sutrisno. (2000).Metodologi Penelitian, Yogyakarta: Andi Yogyakarta.

Iskandar. (2016). Implementasi Teori Hirarki Kebutuhan Abraham Maslom terhadap peningkatan kinerja pustakawan. Jurnal Ilmu Perpustakaan, Informasi, dan Kearsipan Khizanah Al-Hikmah, 4(1), 24-34.Yogyakarta di : https://journal.uin-alauddin.ac.idkhizanahal-hikmah

Jaya, I.G.M.K., I, Gde Adnyana Sudibya, I.G.A. dan I Nyoman Sudharma,I .N. (2017). Pengaruh Lingkungan Kerja dan Motivasi Serta Kompensasi terhadap Semangat Kerja Pegawai Dinas Kesehatan Kabupaten Tabanan. ISSN: 2337-3067. E-Jurnal Ekonomi dan Bisnis Universitas Udayana 6.2 (2017): 533-564 di ojs.unud.ac.id

Kiki Cahaya Setiawan (2015). Pengaruh Motivasi Kerja Terhadap Kinerja karyawan Level Pelaksana di Divisi Oparasi PT. Pusri Palembang.PSIKIS-Jurnal Psikologi Islami.Vol. 1 No. 2.(2015) 43-53 di jurnal.radenfatah.ac.id

Lesmarnil dan Kasmiruddin2. (2015). Pengaruh Pemberian Motivasi Terhadap Semangat Kerja Karyawan Bisnis Perbankan (Studi Penerapan Need Achievment Pada Bank BNI cabang Rengat. Jom FISIP Volume 2 No. 2 Oktober 2015 di: jom.unri.ac.id

Mangkunegara, A. P. (2014). Manajemen Sumber Daya Manusia. Bandung: PT Remaja Rosdakarya di: scholar.google.com

Pratama, A.A.N.dan Aprina Wardani,Aprina.(2017). Pengaruh Kemampuan kerja dan semangat kerja terhadap kinerja Karyawan melalui kepuasan kerja (Studi Kasus Bank Syariah Mandiri Kantor Cabang Kendal).Jurnal Muqtasid, 8(2) 2017: 119-129 di: https://muqtasid.iainsalatiga.ac.id/index.php/muqtasid/article/view/1153

Riyunita, Hasanah. (2016). Pengaruh Lingkungan Kerja terhadap Semangat Kerja Karyawan Bagian Ervice Pada PT.United Tracktor Tbk. Pekanbaru .Jom FISIPVol. 3 No. 1-Februari 2016 di: $\underline{\text { media.neliti.com }}$

Sugiyono. (2014).Metode Penelitian Kuantitatif Kualitatif dan R\&D. Bandung: Alfabeta.

Supriyanto, Heri., dan Mukzam, M.D. (2017). Pengaruh Motivasi Kerja dan Lingkungan Kerja Terhadap Kinerja Karyawan ( Studi pada Karyawan LPP RRI Stasiun Malang). Jurnal Administrasi Bisnis (JAB). Vol. 58 No. 1 Mei 2018 di: http://administrasibisnis.studentjournal.ub.ac.id/index.php/jab/article/view/2415

Syamsudin Bachtiar,Tedy.(2018).Pengaruh Lingkungan Kerja dan Motivasi Terhadap Semangat Kerja Divisi Produksi Karyawan Pada PT. Utama Gas Multi Perkasa Cabang Serang. Jurnal Sains Manajemen.Vol.4.No.1.2018 di: $\underline{\text { http://e- }}$ jurnal.lppmunsera.org/index.php/SM/article/view/654

Sugiono.2014. Metode Penelitian kuantitatif kualitatif R\&D. Bandung: Alfabeta.

Sujarweni, W. (2014). Metodelogi Penelitian. Yogyakarta: Pustaka Baru Press.

Titisari, Purnamie. (2014). Peranan Organizational Citizenship Behavior (OCB) dalam meningkatkan kinerja karyawan. Mitra wacana media: Jakarta.

Utamajaya, I. D. G. A. P, dan Sriathi, A. A. A. (2015). Pengaruh motivasi, Komunikasi, serta 
Lingkungan Kerja Fisik Terhadap Semangat kerja karyawan pada Fuji jaya Motor Gianyar. EJurnal Manajemen Unud, Vol. 4, No. 6, 2015: 1504-1524. https://ojs.unud.ac.id/index.php/Manajemen/article/view/11829

Wibowo. (2015). Perilaku dalam Berorganisasi. Jakarta: PT Rajagrafindo Perkasa. 